\title{
Kadına "Yoksul” Bakışlar: Profanın Dar Dünyasından İslâm'ın Geniş Evrenine ${ }^{1}$
}

\section{"Poor" Approaches to Women: From a Narrow Profane World to a Vast Universe of Islam}

Prof. Dr. Mustafa Tekin ${ }^{2}$

Öz

$\mathrm{K}_{\mathrm{t}}^{\mathrm{s}}$ adın konusu, özellikle Sanayi Devrimi ve modernleşme sürecinden bu yana, tartışmaların odak noktasını oluşturmuştur. Bugün gelinen noktada, şiddetten siyasi temsile, eviçi rollerden kamusal hayata kadar bir dizi problem kadın üzerinden tartışılmaya devam etmektedir. Bu tartışmalar farklı düşünsel bakış açılarında, kadınlar için kurtuluş reçeteleri öneren bir biçimde karşımıza çıkmaktadır. Nitekim feminizm, liberalizm, sosyalizm ve postmodernizmin bakış açılarında kadın bir "konumlandırma" ve "üzerine konuşma"nın konusu olmaya devam etmektedir. Ancak bugün kadın konusunda yaşanan problemler azalmamakta, tam tersine artmaktadır. Kimileri kadına cinsel bir meta olarak yaklaşırken, kimileri de ona varlığını reddeden bir açıdan bakmaktadır. Hiç şüphesiz bu iki nokta arasında salınım gösteren kadına sağlıksız bakışlar, kendilerine dinî, ideolojik, düşünsel, geleneksel referanslar bulmaktadırlar.

Biz kadına sağlıksız bakışların her şeyden önce "zihni yoksulluk”tan kaynaklandığ1nı; zihinde konulan bariyerlerin sağlıklı bakışı engellediğini düşünmekteyiz. Bu bariyerler aslında Türkiye toplumunda İslâm’ın da sağlıksız algılandığını göstermektedir. Daha da ötede kadına yoksul bakışların İslâm’a referansla da doğrulanmaya çalışıldığını görmekteyiz. Kadına yoksul bakışlar da tüm bu karmaşa içinde şekillenmektedir.

Biz bu tebliğde, farklı ideoloji ve yanlış din anlayışlarında kadına bakıştaki yoksulluğu bir problem olarak ele alacağız. Bunu da "zihni yoksulluk” şeklindeki bir kavramsallaştırma üzerinden yapacağız. Daha sonra, İslâm’ın insan ortak paydası altında kadın ve erkeğe yaklaşımı ile onları zihni yoksulluktan kurtaran bakış açısına referansla ve geniş tarihsel tecrübeler ışığında adaletli bir yaklaşımı inşa etmeye çalışacağız. Zihni

\footnotetext{
1 Bu makale, aynı isimle 03.03.2016 tarihinde KADEM tarafından düzenlenen II. Toplumsal Cinsiyet Adaleti Kongresi’nde sunulan bildirinin gözden geçirilmiş şeklidir.

2 İstanbul Üniversitesi İlahiyat Fakültesi Din Sosyolojisi Bilim Dalı Öğretim Üyesi, mtekin@istanbul.edu.tr 
yoksulluğun daraltıcı çerçevesini yoklarken, İslâm’ın evrensel zenginleştirici potansiyellerine işaret edeceğiz.

Anahtar Kelimeler: Kadın, Adalet, Yoksul bakış, Zihni bariyer, Din

\section{Abstract}

$\mathrm{T}$ he concept of women, from the Industrial Revolution and throughout the period of modernization has been the focus point of debates for a long time. Currently, women are used as a means to discuss problems from extremity to political representation; from domestic roles to public life. There are several suggestions for the empancipation of women in various schools of thought. All the while, there is 'positioning' and 'talk' in regards to women in the views of feminism, liberalism, socialism and postmodernism. The problems of women have not decreased, but on the contrary have been on an increase. Some have looked at women as a sexual item and some have denied their entity. Undoubtedly, it is possible to find references of religion, ideology, intellectual thought and tradition in the wrong approaches towards women.

We content that different unsound approaches towards women come from "mental poverty"; and the mental barriers within minds prevent for a sound approach to come about. In further to this, we argue Islam has been perceived incorrectly with these obstructions in society. We can see that the unsalient approaches towards women are attempted to be verified with Islamic sources.

In this paper, we will discuss the poor approaches towards women as a problem in different ideologies and the incorrect understanding of religion. We will use the notion of "mental poverty" in our discussions. Within the worldview of Islam, women and men are both common as they are human. Islam has prevented men and women from mental poverty. We will attempt to construct a healthy view of Islam in light of religious doctrine and vast historical experiences.

Key Words: Woman, Justice, Poor approaches, Mental obstructions, Religion

\section{Giriş}

"Kadın”, çeşitlenen alt başlıklarıyla birlikte bugün sürekli bir tartışmanın konusu olmaya devam etmektedir. Özellikle küreselleşen dünyada iletişim teknolojilerinin de devreye girmesiyle "hız" ve "değişim” sarmalı içinde farklı dünyalarla karşılaşma, tartışmaları daha da derinleştirmekte ve ajandamıza farklı başlıklar eklemektedir. Buna 
ilaveten genelde Osmanlı'nın son döneminden, özelde ise son otuz yıldan bu yana yaşanan değişimler kadınlara dair aktüel tartışmaları hem hızlandırmış hem de ona yeni boyutlar kazandırmıştır. Nitekim kadınların örgün eğitim kurumları içinde artan oranı, çalışma hayatına girişleri, kamusal alandaki aktiviteleri, kadının algılanışı, konumlandırılışı, din-gelenek-kadın arasındaki ilişki ve anlayışlarda bir değişimi beraberinde getirmiştir.

Bilhassa 1980'lerden sonra gerek kadın anlayışına, gerekse kadınların içerisinde bulunduğu diğer sorun ve başlıklara dair yazınlarda ciddi bir artış gözlemlenmektedir. İster istemez değişen sosyolojik şartlara bağlı olarak farklı ideoloji, felsefe ve dinlerin kadına yaklaşımları ve kadın sorunlarına dair önerileri bağlamında bu tartışmaları, gerek akademik ve entelektüel gerekse magazinel ve medyatik düzlemlerde izlemek mümkün olmuştur. Hiç şüphesiz bu yaklaşım ve iddiaların kendi içerisinde negatif ve pozitif açıdan kategorik ayrıştırmaları yapılabilir. Sosyalizm, liberalizm gibi ideoloji ve düşünceler içinden olduğu kadar, İslâm başta olmak üzere dinler içinden de yapılmıştır. Hem bir sosyal hareket hem de bir düşünce akımı olarak feminizm kanadından yapılan değerlendirmeler de yükseliş kaydetmiştir. Fakat her hâlükârda "kadın"la ilgili tartışmalar ve yaklaşımların başat bağlamı ve problemi din olmuştur.

\section{A.A. Araştırmanın Sınırları}

Araştırmanın genel başlığı kadın ve yoksulluk ilişkisi üzerinedir. Bir başka deyişle yoksulluk bağlamında kadın konusudur. "Yoksulluk" kelimesi ilk duyulduğu andan itibaren zihinlerde ekonomik açıdan yoksunluk, mahrumiyet, sınıfsallık gibi iktisadi ve sosyolojik boyutları çağrıştırmaktadır. Özellikle günümüzde kadınlar açısından "ekonomik yeterliliğini kazanma” söylemi, kadın ve yoksulluk tartışmalarında ekonomik boyutu ön plana çıkarmaktadır. Biz de bu sebeple, "yoksul” kavramının daha mecazi bir anlamını kadın açısından mesele yapmaktayız. Dolayısıyla burada "yoksul" kelimesinin mümkün anlamlarından biri olan "eksiklik", "mahrum olma” ya bir atıfta bulunmakla birlikte, yoksulluğu ekonomik değil "bilgi”, "zihniyet” ve "insani potansiyeller” bağlamında mahrumiyet ve eksiklik anlamında kullanacağız. Böylece kelimeyi "ekonomik" içeriğinden uzaklaştırmış olacağız.

Peki başlıkta geçen “yoksul bakış” ile ne kastetmekteyiz? Bakmak ve görmek iki ayrı fiildir. Bilindiği gibi bakmak bir kişi ya da nesneye nazar etmeyi içinde barındırır; fakat "görmek" bakılan nesne veya kişide varolan nitelikler ve ilişkileri kavrayabilmek ve anlayabilmektir. İngilizce’de de "anlıyorum” fiilinin karşılığı olarak "I see” kullanılması da burada güzel bir örnektir. Dolayısıyla "bakmak" görmenin garantisi değildir; ancak görmek için mutlaka bakmak lazımdır (Özel, 1993, s. 107-109). Bakmak fiilinde iki taraf vardır; bakan ve bakılan. Bakış ise, daha çok bakanın karşısındaki muhatabına dair anlama, algılama ve kavrayışlardır. Bakılanın buradaki konumu ve duruşu, "bakış"a etki etmekle birlikte, bakış bakanın değerlendirmelerini içerir. Biz "yoksul bakış" derken, bakan kişinin ya da bir meseleye dair yargılar geliştirmiş bir ideoloji, düşünce, din ve felsefelerin bilgi ve ufuk eksikliği ile zihniyet sorunlarından kaynak- 
lanan bir "bakış"1 kastetmekteyiz. Bu, bazan ideoloji, düşünce, felsefe ve dinin kendi dinamik imkânsızlığından kaynaklanırken, bazan da bunlara bir aidiyet hissetsin ya da hissetmesin kişinin ufuk ve bilgi noksanlığından kaynaklanabilir. Başlığımız tam olarak "kadına yoksul bakışlar" olduğundan özel olarak "kadın"lara bu mahrumiyet ve eksiklik ile malul bakışları konu alacağız. Fakat bu bakış kim tarafından gerçekleştirilmektedir? Biz bunu erkek ve kadınlar kadar ideoloji ve dinler diye cevap vermekteyiz. Peki biz tartışmamızı nereye teksif edeceğiz?

Yukarıda "kadın" konusundaki tartışmalara farklı düşünce ve dinlerin müdahil olduğunu belirtmiştik. Biz burada, direkt ilgisi sebebiyle feminizmin kadına bakışını, özellikle İslâm’ın yaklaşımları ile mukayese ederek sorunu analiz etmeye çalışacağız. Zaman zaman farklı ideolojilere referansta bulunmakla birlikte, temelde feminizm ve İslâm'da kadına bakışın oldukça ihatalı ilişkileri önümüze çıkaracağını düşünüyoruz. Feminizmin liberal, sol, radikal ve hatta İslâmcı versiyonları da göz önüne alındığında, bilhassa aktüel kadın tartışmalarında bu mukayeseli yaklaşımların analizi kapsamlı olacak gibi görünmektedir. Makalemizin alt başlı̆̆ "Profanın Dar Dünyasından İslâm’ın Geniş Evrenine” şeklinde belirtilmiştir ki, bu başlık bir mukayeseye vurgu yapmaktadır. Tabii ki feminizm ve İslâm’ın içinden konuşanların bu düşünce ve dinin temel bakış açısından bağımsız olarak bakış ve yaklaşımları da, bu tartışmanın içeriğinde kaçınılmaz olarak yer alacaktır.

\section{A.B. Araştırmanın Problemi ve Tezi}

Gerek akademik gerekse akademi dışı tartışma ve eserlerde kadına çok farklı yaklaşımlar söz konusudur. Bu tartışma ve eserler, kadını yeniden konumlandırmak ya da var olan konumunu pekiştirmekte veya geçmişe nostaljik bir dönüşü önermektedirler. $\mathrm{Bu}$ anlamda, içeriklerinde bolca kadına özgürlük vaatlerinin yer aldığı da gözlerden kaçmamaktadır. Feminizm de bu iddiaları yaygın olarak dile getiren bir düşünce ve toplumsal hareket olarak dikkat çekmektedir. Kanaatimizce profan, içkin ve hümanist bir dünya görüşünün içinden geliştirilen bu bakış açıları sorunludur. Bu düşüncelerin iddia ve itirazlarında doğru noktalar bulunmakla birlikte, önerilerinin paradigmal anlamda "kadın" realitesini yakalamada problemli olduklarını söyleyebiliriz. Doğrusu zikredilen krizi, bu düşünce ve yaklaşımların krizlerinde izlemek mümkündür. Bizim temel tezimiz, özelde feminizmin "kadın”a dair öneri ve yaklaşımlarının “insan” ve "kadın” gerçekliğine çok mesafeli olduğu; seküler, dualist, içkin, hümanist karakteri ve bağlı olduğu dünya görüşü sebebiyle kadını yoksullaştırıcı bir bakış açısına hapsettiği; bunun karşısında İslâm’nn bütüncül, holistik dünya görüşü sebebiyle insan ve kadına dair hakikati kapsayıcı bir şekilde dile getirdiğidir.

Belki bu noktada, İslâm ile feminizmin, ilki din ikincisi de bir düşünce, toplumsal hareket ve ideoloji olması hasebiyle karşılaştırılmasının uygun olup olmadığı sorgulanabilir. Her şeyden önce feminizmi, bir dünya görüşünün içinden çıkmış kadına dair yoğun iddiaları olması sebebiyle tercih etmekteyiz. Dolayısıyla feminizm, o bağlantılarını kaybetmeden bir tartışmanın konusu olacaktır. Buradan yola çıkarak öncelikle 
İslâm ve feminizmin iki farklı paradigma olarak varlık, bilgi ve değerler konusuna yaklaşımlarını analiz etmeye çalışacağız. Bu analizler, daha sonraki tartışmaların zeminini oluşturacaktır. Ardından "kadına yoksul bakışlar" meselesini özgürlük, kimlik-haklar ve beden başlıkları üzerinden ele almak istiyoruz. Bu başlıklar aktüel kadın tartışmalarının vazgeçilmezleri olması ve meseleyi ihata edebilecek içeriklere sahip olmaları hasebiyle tercih edilmişlerdir.

\section{A.C. İslâm ve Feminizm: İki Farklı Paradigma}

Günümüzde oldukça çeşitlenen kadın tartışmaları, tabiri caizse kitabın ortasından yapılmaktadır. Bir başka deyişle, İslâm ve feminizmin varlık, bilgi ve değerleri üzerinden şekillenen dünya görüşü temel bir zemin olarak ortaya konulmadan (zira paradigmal zemin teferruatta içtihatları daha anlaşılır kılacaktır), çoğunlukla "hadi buna cevap ver" türünden bir meydan okumaya dönüşmektedir. Halbuki İslâm ve feminizmin argümanlarının anlaşılma zemini bu dünya görüşü ve sahip oldukları niteliklerdir. Bu açıdan biz yapacağımız analizlerin boşlukta sallanmaması açısından böyle bir çerçeveyi çizmenin zaruri olduğunu düşünüyoruz.

\section{1. İslâm}

İslâm, bir düşünce, ideoloji, kültür olarak tanımlanamaz ancak o düşüncesi, kültürü, pratikleri ve felsefesi olan bir dindir. İslâm özelde Hz. Muhammed’e (s.a.v.) indirilen dinin adı olsa da, kendi beyanlarına göre ilk insan ve ilk peygamber olan Hz. Âdem'e (a.s.) kadar giden bir geleneğe sahiptir. Bu durum, peygamberler tarihinin aynı hakikatin tarihsel süreçteki uğrak noktaları olduğu gerçeğini bize hatırlatmaktadır. Nitekim toplumlarda değişen sosyal şartlar muvacehesinde pratikte farklı uygulamalar olsa da, özünde İslâm, aynı hakikatin vurgulanmasından ibarettir.

İslâm’a göre varlık temelde iki kısımdır: Mutlak ve mümkün. Mutlak, varlığı kendinden menkul ve zorunlu olması hasebiyle yalnız Allah'tır (c.c.). Bu sebeple O'na "Vâcibu'l-Vücûd" denilir. Mümkün varlıklar ise, varlığı ve yokluğu imkân dahilinde olan, fakat varlığ 1 ancak "mutlak varlık"la imkân dahiline girmesi sebebiyle insan, bitki, hayvan ve âlemdir (Gölcük ve Toprak, 1988, s. 123). Bu açıdan Allah ile insan arasında bir mahiyet farkı söz konusudur. Allah; mutlak, ezelî, âlim ve kadirdir. İnsan ise fâni olup ilmi ve kudreti sınırlıdır. Buna ilaveten İslâm’a göre Allah tektir; kendisi gibi bir başka varlık yoktur. İslâm, buradan yola çıkarak Allah’ın merkezde olduğu ve diğer tüm varlıkların ona göre anlam kazandığı bir ontoloji, epistemoloji ve değerler sistemi kurar.

Bir hakikat olarak bunun insan tarafindan kabul edilmesi beklenir. Allah, insanları yaratmış ve onlardan bir misak (söz) almıştır. Buna göre, ruhlarımıza "Ben sizin rabbiniz değil miyim?" șeklinde bir soru yöneltildiğinde, insan ruhları "Evet, sen bizim rabbimizsin" (Áraf, 7/172) diyerek onay vermişlerdir. İnsanın yaratılması ve dünyaya gönderilme amacı da, bu misakını yerine getirip getirmeyeceği üzerinedir. "Ben cin- 
leri ve insanları ancak bana ibadet etsinler diye yarattım" (Zâriyât, 51/56) şeklindeki Kur'an hitabı, belki bu misakın biraz daha farklı açılımını ifade eder. İnsan dünyaya doğar, yaşar ve nihayet ölerek bu dünyayı terkeder. Kur'an’a göre dünya, insanın nihai amacı olmadığı gibi nihai mekânı da değildir. Misaka dair bir sınama yeri olarak dünya hayatı, insan için kısa bir geçişlik mekânı olup, ebedi yurt ve varış yeri (destination) ahirettir (Ankebût, 29/64).

İnsanın ahirete olan yolculuğunda dört önemli niteliği dikkat çekmektedir. Birincisi, insanın özgürlügüdür. Bu özgürlük Allah’a nispetle oldukça sınırlı olmakla birlikte, sınamanın kurallarına uygun olarak insana bir özgürlük alanı vermiştir. Bu özgürlük İslâm açısından bir şeyi yapabilme ve güç yetirme anlamındadır; yoksa insanın her istediği şeyi yapabilme hakkı değildir. Allah, insan için değersel bir çerçeve çizerken, bu çerçevenin dışında kalanları yapmaktan insanı sakındırır ve uyarır; ancak bunları insanın yapabilme gücü vardır. İnsanın ikinci önemli niteliği iradesi yani seçimleridir. $\mathrm{Bu}$, farklı alternatifler arasında tercihte bulunabilme kapasitesini bize göstermektedir. İslâm literatüründe insan "cüzi irade" dediğimiz bir çerçevede seçimlerini yapar ve bu Allah’’n külli iradesinden en iyi ve en güzeli bilerek yapan mutlak bir iradeden farklıdır. Fakat insan istediğini seçebilme kapasitesine sahiptir ve sınanma da bu seçimleri üzerinden gerçekleşir. İnsanın üçüncü özelliği ise değer üretebilmesidir ve doğrusu onu diğer canlılardan ayıran temel niteliği de budur. Diğer canlıların yaptıkları kendi içgüdülerinin sınırları içinde kalan zarurete dönüşürken, insanın özgürlüğü ve seçimi bir fiili anlamlı kılabilmektedir. Dördüncü özelliği ise, insanın sorumluluk üstlenen bir varlık olmasıdır. Kur’an’ın "emanet”" şeklinde kavramsallaştırdığı sorumluluğun dağlar, gökler, tarafından reddedilip insan tarafından kabul edildiğini belirtir (Ahzâb, 33/72). İnsanın sorumluluğu dünya hayatına bir amaç verirken, hedefsiz salt dünyaya dönük bir yaşamı da eleştirir. İnsan için özgürlük, sorumlulukla birklikte bulunmaktadır ve özgürlük sorumsuzca "keyfe ma yeşa" (dilediğin gibi) bir hayat değildir. Görüleceği üzere İslâm, bir varlık olarak insanı özgürlük, irade, değer ve sorumluluk etrafında kurmaya çalışır. Bu dört kavramın her biri bir yandan birbirini beslemekte ve birbirlerini dengede tutarak kendilerini gündelik hayat içerisinde göstermektedirler.

İslâm’n paradigmasını en iyi anlatan anahtar kavram "tevhit" olsa gerektir. Allah'n varlığı ve birliği çerçevesinde tanımlanan "tevhidin, aslında çok geniş anlam kıvrımları bulunmaktadır. Bütün mevcudatın kaynağının Allah olması, yani insan, eşya ve bilginin aynı kaynakta buluşması; insan hayatını kuşatan her alanın bağımsız ontik bir kategori olmayıp aynı tanrısal hakikatle bağlantılı bulunması, hakikatin çok yönlü tezahürleri vb. tevhidin geniş anlam stokuna referansta bulunmaktadır. Bu bakış açısı, dünyadaki varlıkların tüm çeşitliliğine rağmen tek bir kaynak, amaç ve varlık etrafında mâna ifade ettiğini belirtirken, erkek-kadın kategorilerini de birbirlerinden bağımsız ontik bir kategori olarak görmez.

\subsection{Feminizm}

Feminizm, Batı düşünce tarihi içerisinde ortaya çıkmış toplumsal bir hareket olma 
boyutu da taşıyan bir düşünce ve akım olarak tanımlanabilir. Bu açıdan temel nitelikleri de, batılı bir mantalite içerisinde şekil kazanmıştır denilebilir. Her ne kadar kendi sınırlarında bir iç çeşitliliğe sahip olsa da, son kertede modern Batı düşüncesi içerisinde konumlanmaktadır. Peki feminizmin varlık, bilgi ve değerler konusundaki temel yaklaşımı nasıldır? Feminizm, insan merkezli bir evren ve varlık anlayışına sahiptir. Hümanist bir temelden hareket eden feminizm, Tanrı'yı insana göre konumlandırır. Aslında feministler Tanrı́ya inanmamak ile deist ve oradan teist Tanrı anlayışına kadar geniş bir tayf içerisinde salınım gösterirler. Buna bağlı olarak epistemolojilerinde vahiy, bir kaynak değildir. Değerler de insan merkezli anlayışa göre yeniden şekillenirler. Buna göre verili bir varlık anlayışından mesafe alarak kendi değerlerini kendisi yaratmaktadır. Dolayısıyla feminizm için dünyanın "ilâhî" ile olan bağlantılı bir anlamı bulunmadığından, dünya bir sınanma yeri olmayıp "anlam" 1 tekrar insan tarafından üretilebilen seküler bir mekâna dönüşmektedir.

Peki feminizm için din ve hakikat nerede durmaktadır? Feministler "ataerkillik" ve "erkek egemen anlayış" şeklindeki söylemlerden yola çıkarak tarihi, söylemi ve tüm yaşamı problem haline getirirken, kadınların ikincilleştirilmesi sorunu üzerine odaklanırlar. Onlara göre gelenekle birlikte din de kadının ikincilleşmesinin ve ataerkil bir söylemin üretilmesinin zeminini oluşturduğundan eleştirilmesi gereken fenomenlerdir. Bu mantaliteden yola çıkarak, verili bir dünyayı gündeme getiren "hakikat" anlayışının kabulü mümkün değildir. Modern dönemde bu "hakikat" insan merkezli olarak tekrar kurulurken, postmodern feministler "hakikat" fikrini parçalayarak dayanak noktalarını dağıtırlar. Feminizmde önemli başlık olan "kadın özgürlüğü" nihayetinde dinden özgürleşmeye doğru varır.

Dayanak noktası olarak üst-değerden yoksun olan feminizm için dünya elde kalan tek mekân olurken, "kadın özgürlügüu" de yegâne söylem olarak ortaya çıar. Özgürlük feminizmin ana başlıklarından birisidir fakat bu özgürlüğün referansı yine insanın kendisi olduğundan, temel hedef ve sınırlarda bir muğlaklık söz konusudur. Söz gelimi; ataerkil söylem ve pratikleri beslediği düşünülen din eleştirisinin, en nihayetinde Tanrı ile hesaplaşmaya dönüşmesi kaçınılmazdır. Peki bu nasıl bir düzlemde gerçekleşecektir? Öte yandan kendisi de verili bir varoluşun parçası olan insanın, bu özgürlük anlayışında imkân ve sınırları hesaba dahil edilmekte midir? Dolayısıyla bu özgürlüğün nihai ufku bir "anlam"dan ve dayanak noktasından yoksun gibi görünmektedir.

\section{A.D. Kadın Konumlandırmaları}

Bu başlık altında kısaca İslâm ve feminizmin kadını nasıl tanımladığı ve konumlandırdığına bakacağız. İslâm’ın kadına bakışı konusunda çok fazla spekülasyon ve tartışma bulunmaktadır. Özellikle çağdaş dünyada İslâm’a bu açıdan getirilen eleştiriler dikkate alındığında, "kadın" konusu İslâm’ın yumuşak karnıdır denilebilir. Bu açıdan İslâm’ın kadını nasıl konumlandırdığına spekülasyonlardan mesafe alarak bakmak gerekmektedir. 
İslâm’ın kadını konumlandırışı varlık anlayışı çerçevesinde gelişmektedir. O, mutlak varlık olan Allah’ın karşısında bir insan ve sorumlu bir varlıktır; "ikinci cins" aşağg statüde (inferior) bir tür değildir. Kur’an "biz sizi bir erkek ve dişiden yarattık" (Hucurât, 49/13) derken, öncelikle "insan" tak paydası altında bir cinsiyet olarak konumlandırmaktadır. Kadınla erkek arasında tabii ki biyoloji, duygu yoğunlukları ve nesneleri algılamada bir perspektif farkından bahsedilebilir. Ancak farklılık, bir hiyerarşi yaratmayıp imkân ve potansiyellere işaret etmektedir. Bu açıdan kadın ve erkek birbirini tamamlarlar. Belki bu noktada feminist bakış açısının bir handikabına işaret etmek yerinde olur. Feminist söylemin alt satırları dikkatle okunduğunda, kadınla erkek birbirine benzetmeye çalışılır ve kadını gizli bir erkekleştirme dili sezinlenmektedir. Ayrıca feminist söylem, farklılıkların birbirini tamamlama niteliğini vurgulamak, bunların "insan"lığı nasıl zenginleştirici imkânları beslediğini göstermek yerine, paradoksal olarak erkeği merkeze almakta ve erkekle kadın arasında bir rekabet konsepti kurmaktadır. Halbuki fizik âlemdeki kesret ve farklılıkların gördükleri işlev, onları nasıl birleştirip bir tek kaynağa bağlıyorsa, cinsiyetler de birbirini tamamlayarak "insan"lıkta bütünleșip, insanlığı zenginleştirirler. Kur’an "mümin erkek ve kadınların birbirlerinin velisi” (Tevbe, 9/71) olduğunu söylerken, uzun vadede kadın ve erkeğe çizdiği ufuk budur. Kadın Allah ile erkek üzerinden bir ilişki kurmaz; O Allah’ın karşısında bir kişilik ve sorumlu bir varlıktır.

Feminizmin kadını konumlandırması, Hıristiyanlığın kadın algısına bir cevap ve itiraz niteliği taşımaktadır. Hıristiyanlığa göre, bütün insanlar Hz. Âdem ve Hz. Havvảnın işledikleri yüzünden günahkar doğmaktadırlar (original sin). Kutsal kitabın anlatımlarına göre, bu günahın asıl müsebbibi kadındır. O, Âdem’i baştan çıkararak Tanrı'ya karşı isyana sevketmiştir (Tekvin, 3/6). Bu bakış açısı, daha baştan insanı günahkar kabul ettiği gibi, Havva’yı da esas suçlu olarak mahkum etmektedir. Hz. Îsâ (a.s.) insanlığın bu günahına kefaret olarak çarmıha gerilmiştir. Kurân-1 Kerim de Âdem ve eşinden bahsetmekte, onların yaptıklarını bir suç olarak görmekte; ancak kadını iğva edici olarak tanımlamamaktadır (Bakara, 2/36). Kur'an’ın dili her ikisinin de bu suçu işleyerek hata ettikleri yönündedir. Doğrusu bu dil ve anlatım, Kur’an’nn insanın seçimleri ve sorumluluğu açısından erkek ve kadını eşit statüde gördügünü bize göstermektedir. Belki de bu sebeple feministlerin "lanetli Havva imajından kurtulmak" (Berktay, 2000, s. 18) ve "yasak meyveyi (ki bu tanrısal bilgi şeklinde tefsir edilir) yemeye cesaret etmek" (Berktay, 2000, s. 216) şeklindeki söylemler, aslında H1ristiyanlığın kadın imajına bir itirazı ifade etmektedir.

Modernizmin ayrılmaz niteliklerinden birisi de sekülerleşmedir. Sekülerlik, dinsel etkinin giderek zayıflaması olduğu kadar, kutsal-profan, dünya-ahiret, ruh-beden şeklindeki dualitelerin oluşmasına atıfta bulunmaktadır. Aslında bir hakikatin birbiriyle ilintili iki yüzü olan bu kavram çiftleri, birbirlerinden bağımsız kategorilere dönüşmüşlerdir. Bu parçalanma, kadın-erkek söz konusu olduğunda da kendisini göstermiş ve cinsiyetler feminist söylemde iki bağımsız kategori haline gelmiştir. Feminist söylemde, kadın ile erkek arasında kurulan rekabet ilişkisi de buradan kaynaklanmaktadır. Aslında Antik Roma’dan beslenen modern zihniyet çerçevesinde kadın ve erkek 
mitolojideki Zeus ve Promete arasındaki çatışmanın (Erhat, 2003, s. 254-257) bir başka rivayeti olarak feminizmde kendisine yer bulmaktadır. Radikal feminist söylemde, erkek-kadın ilişkisi neredeyse bir savaş anlamında ortaya çıkmaktadır. Burada asıl sorunun, Batı'da en başından beri var olan düalist dünya görüşü olduğunu belirtmeliyiz. Kadın-erkek ilişkisinin genel durumu da bu dünya görüşü içinden belirlenmektedir.

\section{A.E. Kadına Yoksul Bakışlar}

Kadın konusuyla ilgili tartışmaların alt başlıklarda olabildiğince çeşitlenmiş olduğunu daha önce belirtmiştik. Bu alt başlıkların herbirini burada tek tek tartışmamız sınırlarımızı aşacaktır. Bu sebeple, meseleyi tartışmak üzere üç başlığın hem aktüel olarak hem de evreni temsil etmek üzere yeterli olacağı kanaatini taşımaktayız. Bunlar; özgürlük, kimlik ve haklar ile beden olacaklardır. Şimdi bunları ele alabiliriz.

\section{1. Özgürlük}

Özgürlük bugün özelde kadın söz konusu olduğunda, neredeyse tartışmaların nirengi noktasını oluşturmaktadır diyebiliriz. Bilhassa feminizmin kadına dair taleplerinin özünü “özgürlül”” konusu oluşturmaktadır. Feminist söylem, aslı itibariyle kendisini kadına özgürlük mücadelesiyle tanımlar ve konumlandırır. Bu açıdan feminizm, yalnızca gerçekliği bir yaşama yolundan ziyade kamu hayatı, özgürlük ve farklılığı bir tecrübe tarzı olarak ortadadır (Giannessi, 2004, s. 447). Feminizmin kadına özgürlük söyleminin ana çerçevesi, aslında onun varlığa bakışıyla paralellik arz etmektedir. Bu bağlamda, kadına erkekle rekabet içerisindeki bir konseptte özgürlük aramakta ve insan hayatını kuşatan aile, din ve geleneği kadın özgürlüğü önünde çoğunlukla engel olarak görmektedir. Hatta feminizmin radikal versiyonuna doğru ilerledikçe, kadın özgürlüğünün dinden özgürleşme anlamına geldiği anlaşılmaktadır. Nitekim dinin kadınları tek bir kalıbın içine hapsederek bağımlılıklarını içselleştirmede meşruiyet sağladığından hareketle, özgürleşme ve kendini gerçekleştirme çabasında olan bütün kadınların bir ideoloji olarak tek tanrılı dinlerin insan yaşamını sınırlandırma, insanı kendisine yabancılaştırma, dinlerin dayattıkları toplumsal cinsiyet kalıplarını ve eşitsiz cinsiyet ilişkilerini sorgulama; yani din olgusuyla hesaplaşma gereksiniminden bahsedilmektedir (Berktay, 2000, s. 12-13).

Dinden özgürleşme çok farklı açllardan feminizme konu olmaktadır. Burada öncelikli öne çıkan tartışmalardan birisinin din ile serbest cinsellik arasındaki gerilim olduğunu söyleyebiliriz. Zira kadın cinselliğinin serbestliği özgürlüğe eklenen sembolik bir gösterge haline gelmiştir (Tekin, 2004, s. 297). Böylece toplumda mevcut kadın-erkek ilişkileri yeni bir düzenlemenin konusu olmaktadır. Yazınlardan anlaşıldığı kadarıyla, bu cinsel serbestiyet var olan sınırların yıkılabileceğine dair bir görüşü ifade etmektedir (Coward, t.y., s. 97). Burada kadın özgürlüğü önündeki asıl problem, evlilik ve çocuk olarak ortaya konmaktadır. Tam da bu sebeple feminist söylem, üreme ile cinselliğin arasını ayırarak, bu özgürlüğü sağlayacağını düşünmektedir. Söz gelimi; Simon De Beauvoir'e göre, hamilelik kadınları pasifleştirmektedir (De Beauvoir, 1977, 
s. 513-513). Özellikle 1960 sonrası gelen ve kadının kurtuluşunu merkeze alan yeni dalga feminizm akımı, kadını her alanda özgür ve bağımsız kılmak istemekte, çocuk gibi cinsiyet bağlantılı tüm rollerden onu azade kılmak istemektedir (Çaha, 2010, s. 56). Dolayısıyla evlilikten başlayarak hamilelik ve çocuğa kadar tüm süreç, özgürlük açısından sorunsallaştırılmaktadır. Bu sebeple evlilik, bilhassa radikal feministlerce kadına eziyetin bir formülleştirimi olduğundan kesin bir ret ile karşılaşmaktadır (Donovan, 2001, s. 271-272). Burada evlilik ve ailenin dinsel bağlantılarından boşand1rılarak tanımlanması (Chesser, 1972, s. 163-166) netice itibariyle bunları kadınların omuzlarında bir yük olarak sunmaktadır. Hatta bazı radikal feministler geleneksel aileyi tamamen reddederek bunu kadını mahveden bir sistem olarak görmektedirler. Bu bakış açısına göre, gerçek özgür kadın, erkeksiz yaşayabilmesinden dolayı lezbiyen kadındır. Dolayısıyla bir kadın, temas olmadan da çocuk sahibi olabilecektir. Geleneksel heteroseksüel ilişkiler artık bir norm olarak değerlendirilemez ve kadınlar kendi seksüel tercihlerini ifade etmede tamamen özgür olmalıdırlar (Kirk, 1987, s. 26). Dikkat edilirse bu söylemlerde kadın özgürlüğünde erkek ile tabii ilişkiler de bir probleme dönüşmektedir.

Dolayısıyla din bağlamında "erkek" ile ilişkiler de, kadın açısından bir özgürlük sorunu şeklinde tanımlanmaktadır. Feminizmin bu konudaki genel söylemi, kadının özellikle gelenek ve dinler tarafından kadını erkeğe tâbi kılma ilişkisi geliştirdiği yolundadır. Erken dönem feminist yazarlardan Wallstonecraft, kadına insan türünün bir parçası olarak değil, doğuştan erkeğe tâbi bir varlık şeklinde bakılmasının $\mathrm{Mu}$ hammedîliğin özüne uygun olduğunu (Wollstonecraft, 2007, s. 10) belirtmektedir. Bu tabiiyet ilişkisi söylemini dinin meşrulaştırdığı sonucuna ulaşılmaktadır. Meselâ bu teze göre, "cinsel arzunun tamamen meşru kabul edildiği fakat Tanrı'dan uzaklaştırıcı gücünden kaynaklanan endişeler yüzünden kurallara bağlandığı Müslüman toplumunda, vücudun ritüel temizliğini akıl yoluyla kontrol etme kapasitesi çok büyük önem kazanmaktadır. Kadınların doğaları gereğince söz konusu kontrol olanağını kullanmalarının imkânsızlığı, onların toplumun düzeni açısından potansiyel bir tehdit olarak algılanmalarının en önemli nedenlerinden birisini oluşturmuştur. Kadının kontrol edemediği vücudu, cemaatin ahlâki bütünlüğünün garantisi olan iç/dış dünyaların sembolik ayrımının muhafazasını tehlikeye sokar. Böylece bu ayrımı savunma görevi erkeklere bırakılmıştır; onlar, kadınların vücudunu kontrol altında tutarak ümmetin ritüel temizliğini ve ahlâki bütünlüğünü gözetirler.” (Saraçgil, 2005, s. 43).

Burada cinsiyetler arası bir rekabet ilişkisi görülmektedir ve feminist söylemin zihni arka planında bu, tanrı ve tanrıça arasındaki ilişkilerin bir yansımasıdır. Buna göre, erkek tanrının doğumu ile kadınlara yönelik bir şiddet gerçekleşmiştir ki, temel göstergesi Kâbe'de bulunan ikonların kırılıp parçalanmasıdır. Yıkım ve şiddete en uzun süre dayananlar da Lat, Menat, Uzza isimli tanrıçalardır (Sabbah, 1995, s. 40). Anlaşıldığı kadarıyla kadının cinsel özgürlüğünü yaşayabilmesi aile, evlilik, erkek ve dine dair sınır(sızlık)ların yeni tanımını gündeme getirmektedir. Zira, kadın özgürlüğünün feminizm açısından problem olması, kadına dair sınırların toplumsal süreçlerle sürekli yeniden çizilmesi gibi görünmektedir (Butler, 2009, s. 74). 
Tabii ki bu söylemlerin Türkiye'de de önemli oranda karşılıkları oluşmaya başlamıştır. Buradaki özgürlük tartışmalarının da odak noktasında din ve özelde İslâm görünmektedir. Bu bağlamda kadın özgürlüğünün önündeki bir başka engelin tesettür olduğu ve tesettürlü kadın imajının kamusal alanda kendi içine kapanmış bedeni imlediği (İlyasoğlu, 1994, s. 112-113) ifade edilirken, bu durum kadının sosyal hayatın dışına itilmesi (Çalışlar, 1991, s. 141) şeklinde yorumlanır. Böylece başörtüsü üzerinden İslâm’ın kadını görünmezliğin ve sessizliğin simgesi haline getirdiğinin altı çizilmektedir (Sirman, 1995, s. 248). Dolayısıyla bu söylemde başörtüsü ve tesettür, çoğunlukla bir özgürlük sorunu olarak yer almaktadır.

Feminizmin özgürlük söyleminde dikkat çeken üç nokta vardır. Bunlardan ilki, kadını erkeğe tabi kılma söylemi; ikincisi kadınlar için istenen özgürlük ve onun içeriği; üçüncü nokta da, bu özgürlüğün büyük oranda dine karşı mücadele ile elde edileceğidir. Şimdi feminist söylemin aslında kadınlara ne önerdiğine bakabiliriz.

Her şeyden önce feminizmin "özgürlük" söyleminin insan, kadın ve onların hakikati söz konusu olunca durduğu yer ciddi problemlidir. Bir kere seküler ve hümanist karakterli bu özgürlük söyleminin, metafiziksel temellerinin olmaması, bu özgürlük için anlam problemini ortaya çıkardığı gibi daha çok materyalist bir zemine oturtmaktadır. Daha da önemlisi profanın dar dünyasıyla sınırlılığı, bu özgürlük söyleminin kadın ve insanın hakikati ile buluşmasını engellemektedir. Zira ölümden sonrasının, aşkın varlığın bir hakikat olarak tartışmalara dahil edilmediği görülmektedir. Halbuki ölüm bir gerçektir.

İlk olarak feminizm, kadınlara birçok alanda özgürlük vadetmektedir. Cinsel özgürlük, çocuk doğurmama, kürtaj ve hatta dinden bağımsızlaşma bunların başında gelmektedir. Hatta toplumsal süreçlere, gelenek ve dine eleştiri getirirken, bu özgürlüğün sınırlarını epey genişlettiği izlenimini bize vermeye çalışmaktadır. Burada temel sorularımız şunlar olacaktır: İlkin, bu özgürlük vaatlerinin gerçekleşme imkânları nedir? İkincisi ve daha önemlisi ise, bu vaatler insan ve kadın gerçeği ile ne derece örtüşür? Zira sorun özgürlük vaad etme değil, insan ve kadın için bu vaatlerin bir özgürlük getirip getirmeyeceğidir. İnsanlara uyuşturucu kullanma özgürlüğü verseniz bile, bunun insanları özgürleştirdiğini söyleyebilir misiniz?

İslâm öncelikle insanın özgürleştirilmesini talep eder. Bu sebeple bir insanın diğerine kulluğu, nefsi arzulara bağımlılık, dünyaya bağllık özgürleşme için kaldırılması gereken engellerdir. İnsana fücuru ve takvasını veren Allah (Şems, 91/8) insan için bazı sınırlar da koymuştur. Bu sınırlar aslında onun insanlık imkân ve potansiyellerini koruması ve kendisini gerçekleştirmesi içindir. Bu anlamda bedeninin taleplerini meşru yoldan giderirken, nefs-i emmâresinin sürekli kendisine "fücur"u buyuran şeylere direnmesi, kendisini gerçekleştirmesinin önemli bir adımıdır. Yoksa "nefsini ilâh edinen" (Furkan, 25/43) ifadesinde belirtildiği üzere nefsi onu ele geçirir ve insan onun karşısında özgürlügünü yitirir. Bu açıdan insanın (kadın ve erkeğin) her talebini bir özgürlük olarak okumak doğru değildir. Bir kere feminizm kadın gerçeğini 
verili bir dünyaya gelişi, burada bulunuşunun anlamı, sorumluluğu, ölümü, Tanrı ile ilişkisi gibi hakikatlerden bağımsız ele almakta, hatta bu hakikate karşı sadece "dünya" ile sınırlı şekilde kadını konumlandırmakta ve bu hakikate direnç göstermeyi özgürlüğün bir gereği görmektedir. İslâm, kadını bu hakikat zaviyesinde ele almakta, sadece dünya ile sınırlamamakta, aynı erkek gibi insanlık ortak paydası altında onu konumlandırarak sorumlu tutmaktadır. Dolayısıyla feminist söylemin ilk zafiyeti bu "hakikat" e uzaklığı ve dolayısıyla kadını profanın dar dünyasıyla sınırlandırmasıdır. Feminizmde kadın, ulvi amaçları bulunmayan kapalı bir dünyada yaşamaktadır. Bu ise kadına, yoksullaştırııı bir bakış açısıdır.

İkinci olarak, aile, toplumsal değerler ve erkeğin birçok feminist yazında kendilerinden kurtulunması gereken ögeler şeklinde tanımlanması, aslında özgürleştirici değil sınırlandırıcı bir durumdur. Nitekim feminizmin evlilik dışı ilişkiler ve serbest cinselliği kadını özgürleştirici fenomenler olarak kabul etmesi, sonuçlarının ne olduğu hiç dikkate alınmadan yapılan ve nihayetinde kadını metalaştırmaya götüren taleplerdir. Bir kere cinsel serbestiyet, kadın-erkek ilişkisinde sürekli kadını mağdur eden ve erkeği kadına ve çocuğa karşı sorumluluklarından azade eden sonuçlar doğurmaktadır. Çünkü serbest ilişkilerin sorumluluk ve yük kısmı kadında kalmaktadır. Üstelik tarihsel ve aktüel gerçekler göstermektedir ki, serbest cinsel ilişkiler kadını cinsel bir meta olarak kurumsallaştırmaktadır. Umumhaneler, randevu evleri vb. sürekli erkek cinselliğini merkeze alarak kadınların metalaştırıldığı yerlerdir. Bu metalaştırma sonucu, kürtaj da bir hak olarak feminist talepler içerisinde yer almakta ve hatta özgürlük söyleminin içine dahil edilmektedir. Fakat burada da iki sorun bulunmaktadır. Birincisi, serbest cinsel ilişkilerde biyolojik olarak çocuğun babası nasıl bilinecektir? Bunu bilmeye kadın ve erkeğin, en fazla da çocuğun hakkı yok mudur? İkincisi de, kadın bedeninde anneden ayrı bir varlık olan ceninin hayat hakkının sonlandırılmasına kim, nasıl ve hangi gerekçelerle karar vermektedir? Ceninin yaşam hakkı yok mudur? Zira bu feminizmin sıkça kullandığı "bedenim benimdir" felsefesi ile de paradoks oluşturmaktadır. Zira cenin annenin bedeni değildir. O halde bunu nasıl bir özgürlük olarak okuyabiliriz?

Geçmişte Eflatun, kurguladığı ütopik "Devlet”inde çocukların annelerinden alınarak, devlet için yararlı olmak adına bir başka mekânda büyütülmesini savunuyordu (Eflatun, 1988, s. 146). Benzer kurguları komünizm de yaptı. Meselâ; yine özgürlük adına Wilhelm Reich, bir toplum hayal ederken serbest cinsel ilişkiler, kürtaj ve kadınların çocuklarını tanımadan farklı ailelerde büyütülmesini önermektedir (Reich, 1980). Bu önerilerin, kadının insanlık boyutu, duyguları, çocuğa olan nispeti ve aidiyeti, anne-çocuk ilişkisi ve insan fitratı gibi gerçeklikle arasındaki mesafe oldukça büyüktür. Böyle bir toplumda da, serbest cinsellik daha çok kadının aleyhine işleyecektir. Şunu belirtmek lazımdır ki, Batı'da en fazla şikâyet unsuru olan noktalardan birisi de, insanların erken yaşlarda serbest cinsellik yaşamış olmalarıdır (Polonsky, 1997, s. 118119). Bu, sadece kadını değil, insanlığı da yoksullaştıran bir öneridir. Bilindiği gibi, bugün Batı nüfusu giderek gerilemektedir. Tüm bu sonuçlara göre, serbest cinsellik kadını özgürleştiren değil, onu cinsel meta haline getiren ve aslında aile kurma, toplu- 
ma katkı sunma potansiyellerini yoksullaştıran bir öge olarak karşımıza çıkmaktadır.

Burada şu noktayı da belirtmeliyiz ki, İslâm’da erkeğe kadını denetleme görevi verilmemiştir. Her iki cins de öncelikle Allah’a karşı sorumlu varlıklar olarak yükümlülüklerini yerine getirir ve birbirlerini uyarırlar. İslâm, kadın cinselliğinin kontrol edilemezliğini de beyan etmez; dolayısıyla erkeğin kadını kontrol diye bir görevi yoktur. Her cins kendisinden sorumludur ve sınırlarına dikkat edecektir. Mümin erkek ve kadınlar yanlışlar karşısında birbirlerini uyaracaklardır. Diğer önemli bir nokta da, kadının başörtüsünün onun sessizliği, ikincilliği, pasifize edilmesi ve hayatın dışına atılması şeklinde yorumlanması gerçeği yansıtmamaktadır. Tam tersine başörtüsü kadının kamusal yaşamdaki varlığının bir göstergesidir. Kadın evde zaten mahremleri yanında başörtüsü ile durmaz. Bu anlamda başörtüsü ve tesettür kadının cinsel anlamda metalaşmasının önüne geçme ve kadına kamusal özgürlüğünü sağlamaya matuftur. Böylece kadın bir fert, bir kişilik ve kamusal varlık olarak özgürleşmiş olur. Bu arada bir noktaya temas etmeliyiz. Anlatılanlar kadının özgürlügü noktasında İslâm dünyasında sorunların olmadığı anlamına gelmez. İslâm’ın bu bakış açısına uygun olmayan ve kadını mağdur eden düşünce ve pratikler vardır. Onlar da aslında kadının imkân ve potansiyellerini görmedikleri için ona yoksullaştırıcı bir gözle bakmaktadirlar.

Feminist söylem, kadın özgürlüğünde dinle hesaplaşma ve dinden özgürleşmeyi bir ön koşul olarak ortaya koymaktadır. Ancak dinler, insanları ve bu arada kadınları kendi hakikatleri ile yüzyüze getirmektedir. Dinlerin insan ve özelde kadın için de koyduğu sınırlar tabii ki vardır. Ancak bunlar kadın olarak onların kendilerini gerçekleştirmeleri açısından düşünülünce özgürleştiricidir. Kadına cinsel serbestlik vermek (tabii erkeğe de) onu özgürleştirmediği gibi, kadının gerçekliğini, kendi imkân ve potansiyellerini yakalaması açısından da yoksullaştırıcı bir rol oynamaktadır. Zira sorun "çok özgürlük veriyoruz" şeklindeki söylemlerle vaatler buyurmak değil; bunların insan gerçekliğine (=kadın gerçekliğine) tekabül edebilmesidir.

\subsection{Kimlik ve Haklar}

Kadın kimliğine dair tartışmaların odağında din, önemli bir gerilim noktası gibi görünmektedir. Feminist söylem, özgürlükle de bağlantılı olarak kadının sadece ev içi rollerle sınırlı tanımlanmasına yönelik eleştirilerini sıralarken ataerkillik, kadın-akıl ilişkisi ve kadınların statüsünü de problem haline getirmektedir. Bu da son kertede haklar sorununu ajandamıza taşımaktadır. Öncelikle feminizmin kimlik ve haklar bağlamında gelenek ve bazan dine referansl, sosyal hayattaki pratiklere yönelik itirazlarında haklı yerlerinin olduğunu belirtmeliyiz. Fakat asıl sorun, feminizmin içinden baktığı dünya görüşünün nihai anlamda kadına dair sağlıklı bir konumlandırma yapmaması ve işi bir noktadan sonra kadın ile hakikat arasındaki bir gerilime dönüştürmesidir.

Feminist söylem, kadın kimliğinin inşasında kadın-erkek arasındaki tezat ve gerilim 
ilişkisini devam ettirmekte; bunu da tanrıça ile tanrı arasındaki iktidar mücadelesine refere etmektedir. Kanaatimizce bunun temel sebebi Zeus-Promete çelişkisine kadar giden seküler bir evren algısıdır. Feminist söylem, tarihin ilk aşamasında ana tanrıçanın tek tapınılan nesne iken, daha sonra değişimle erkekleri temsil eden heykelciklere yerini bıraktığını (Michel, 1993, s. 25) iddia etmektedir. Dolayısıyla tanrıça ve erkek tanrı arasındaki mücadele bir kadın-erkek, hatta daha ileri giderek bir Tanrı-kadın gerilimine dönüşmektedir. Bu da "hem kadınların hem de erkeklerin bilincindeki var olan Tanrı kavramını tahtından indiremedikleri sürece, kadınların hiçbir zaman tam bir insan olarak belli bir güç elde edemeyecekleri (Tong, 2006, s. 163) iddias1nı feminist söylemin merkezine yerleştirmektedir. Burada dikkat çekmemiz gereken iki nokta bulunmaktadır. İlki, bir kadın-din gerilimidir ki, nihayetinde bir hakikat söylemi olarak dinden, feminizmin ve dolayısıyla kadın konumlandırmalarının mesafeli oluşudur. İkincisi de, kadınla erkek ilişkisini sürekli bir rekabet ve çatışma ekseni üzerinde kurmasıdır ki, bunun ontolojik kökenlere dayanması feminizmi daha da sorunlu kılmaktadır. Bu anlamda kadınların haklarını kazanabilmesi ancak Tanrı ve erkek aleyhine gelişmelerle mümkün olacaktır. Kur’an, "Mümin erkek ve kadınlar birbirinin velisidir" (Tevbe, 9/71) şeklindeki önerisi ile bu rekabeti bir yardımlaşma ilişkisine dönüştürmekte; erkek ile kadını birbirini zenginleştiren ve katkı sunan "insan"lar olarak görmektedir.

Erkek ve kadın arasındaki ilişkiyi feminist söylem de fark kavramına referansla açıklamaktadır (Felski, 2000, s. 73). Ancak satır araları iyi okunduğunda, bu farkın neredeyse iki ayrı tür olarak kadın ve erkeği düalist bir şekilde konumlandırdığı görülecektir. Feminizme göre bir kadın olmak bir erkek olmaktan farklıdır (Phillips, 1987, s. 4). İslâm açısından kadın ve erkek iki ayrı cinsiyet olmak bakımından kendilerine özgü vasıflara sahiptirler. Ancak bunlar, birbirlerine katkı vererek "bütün" ve "tamam" haline gelirler. Dolayısıyla farklılık bir zenginlik olarak ortaya çıkmaktadır. Ancak feminist söylemde bazan örtük bazan da açık şekilde kadını erkeğe yaklaştırma ve benzeştirme sezinlenmektedir. Bu ise, "kadın”lığın imkân ve potansiyelleri ile erkek, aile ve toplumu zenginleştirmek yerine, kadını kısırlaştırıcı ve tabii potansiyelleri yok edici veya yoksullaştırıcı bir rol oynamaktadır. Böylece modern zamanlar, kadınla erkeğin birbiriyle yarıştırıldığı bir realitenin görünürlüğü ile zihnimize kazınmıştır. Kadın kimliğinde ikinci önemli nokta da, aklın erkeğe içkin kılınarak tabiat-kadın, akıl-erkek özdeşliğinin kurulmasıdır. Feminist söylemde özdeşleştirme kutsal metinlere dayandırılmaktadır. Buna göre "Philo'nun yeniden yorumladığı Tekvin hikâyesinde duyu algısını simgeleyen kadın, zihni simgeleyen erkeğin düşüşünün kaynağı” (Lloyd, 1996, s. 46) olarak gösterilmektedir. Yine birçok hikâyeler de kadınların kötü şeyler yapma eğilimini ispatlamaya yönelik anlatılar içermektedir (Alexandrian, 1993, s. 75). Kur'an, insanın cennetten düşüşü ile ilgili anlatımında ise sadece Havva'yı, yani kadını suçlayıcı bir dil kullanmaz. Dolayısıyla kadına dair bu negatif algıların, dinî metinlerin kültür ve geleneğin içinden yeniden okunarak elde edildiği anlaşılmaktadır. Bu bağlamda kadın-erkek arasındaki çatışmacı dilin tabiat ve akıl arasında da kurulmaya çalışıldığı ve buradan aklın tabiata hegemonyasına gidildiği de gözlenmektedir ki, erkeğin kadın üzerinde hegemonyasının meşrulaştırılması işlevini gör- 
mektedir. Halbuki akıl, irfan ve duygu her iki cinsiyette de bulunmaktadır. Burada şu noktanın vurgulanması kanaatimizce önem taşımaktadır: Kadın ve erkeğin bakış ve algılayışlarında tabii ki farklılıklar bulunmaktadır. Kadın bakışı ve perspektifi, olayları farklı şekilde değerlendirecektir. Zaten bu bakış açısı ve perspektif zenginleştirici bir rol oynamaktadır. Tam da bu noktada, Giddens'in bir araştırmaya referansla söyledikleri önemlidir. Buna göre, "kadınların çoğunluğu erkeklerin çoğunluğuna karşıt olarak, dış dünyaya girişlerini bağllıklar oluşturmakla özdeşleştiriyorlar. Bir çok yorumcunun farkettiği gibi, bir birey hâlâ bekâr, gelecek ilişkileri de sadece beklenti düzeyinde olsa bile, erkekler normalde ben terimleriyle konuşurlarken, kadın benlik anlatıları ise biz terimlerinde ifade ediliyor (Giddens, 2010, s. 54). Görüleceği üzere kadınlar toplumsal ünsiyet, ilişki kurma ve biz duygusunun oluşturulmasında merkezi bir rol oynamaktadırlar. Dolayısıyla "kadın"sı katkının altını çizmek gerekir. $\mathrm{Bu}$ açıdan kadını erkekle rekabet ilişkisi içine sokan ve kadınları aslında homojen bir erkek kimliğinin içinde tanımlayan söylemlerin gerçekte ne kadar yoksullaştırıcı olduğu ortadadır.

Feminist söylemin önemli itiraz noktalarından birisi de, kadının sadece ev içi rollerle tanımlanmasıdır. Doğrusu burada bir kimlik sınırlandırması bağlamında haklı olduğu yerler bulunmaktadır. Zira kadın, toplumsal bir varlıktır ve insan olarak ev dışında da sorumluluk ve roller taşımaktadır. İslâm açısından kadının, Allah’a karşı sorumluluklarını yerine getireceği düzlem toplumdur. O, değer üretecek, insanlara hakikati bildirecek ve üzerine düşeni yerine getirecektir. Bilhassa Peygamber günlerinde kadınların rol ve statüsüne dair örnekler, bu konuda oldukça aydınlatıcıdır. Fakat süreç içerisinde kadınların rollerinde bir daralma olduğu görülmektedir. Geleneksel olanın bakış açısı ve din adına bazı yorum ve pratiklerin burada kadın için yoksullaştıııcı etkilerinden bahsetmemiz gerekmektedir.

Fakat öte yandan feminizmin belki de buna tepki olarak kadınların ev içi rollerini reddetme yoluna gitmesi bir başka yoksullaştırıcı bakış açısıdır. Zira bu bakış açısında kadının kendisini varoluşsal olarak gerçekleştirebileceği annelik, eşlik ve hatta kadınsı diyebileceğimiz nitelikler bir kimlik unsuru olarak dışlanırlar. Meselâ; evliliğin kadınlara eziyet etmenin temel bir formülleştirmesi olduğunu kabul ile bu kurumun reddini radikal feministler önerirler. Bu amaçla da üyelerinin üçte birinin bir erkekle birlikte yaşayabilmesine izin veren bir üyelik kotası koymuşlardır (Donovan, 2001, s. 272). Evlilik ve annelik ile ilgili bu itirazlar feminizmin farklı yorumlarında sürekli bir tartı̧̧ma konusudurlar. Halbuki kadınlar için aile ve çocuk bir başka kendini gerçekleştirme aracıdır.

Kadınların hem rolleri hem de hakları bağlamında ev dışı ilişkileri de tartışmanın bir başka boyutudur. Feminist söylem, özellikle sanayi devriminin ardından kadının ev içi üretimlerinin değersizleşmesini de arka planda tutarak, onun eğitim, çalışma hayatı ve hakları üzerinde durmuştur. Burada kanaatimizce temel sorun; kadının tamamen ev içi ya da dışı rollerden biri ile tanımlanmasıdır. Diğer yandan feminist söylemin kapitalizm ve sosyalizmin kadına yönelik önerilerini yeteri kadar problem 
haline getirmediği ve biraz da bu ideoloji ve yaşam tarzlarının içinden kadına baktığını görmekteyiz. Söz gelimi; sosyalist feministler kapitalizm, sınıfsallık ve kadın ilişkilerine bir problem olarak yoğunlaşırken, liberal feministler de tersini yapmaktadırlar. Halbuki her iki bakış açısı da eksikliklerle maluldür ve uygulamada kadın için ciddi mağduriyetler getirmişlerdir. Meselâ; hâlâ eşit işe eşit ücret bir sorun olarak ortada durmaktadır. Ancak kapitalist sistem bu ucuz iş gücüne dayanmaktadır. Dolayısıyla kapitalizmin içinden kadınların bu mağduriyeti nasıl giderilecektir? Kadınlar hâlâ çok düşük ücretlere çalıştırılarak maddi anlamda yoksullukları pekiştirilmektedir. Maddi anlamdaki yoksulluk ise, çoğu zaman zihni ve manevi yoksulluk ile kendi imkân ve potansiyellerini ortaya koyamama sonucunu doğurmaktadır. Sosyalizmin kadınlar için ne tür mağduriyetler yarattığı da tarihsel olarak sabittir. Bu arada dünya sisteminin özgürlükten, eğitim ve çalışmaya kadar tanıdığını söylediği haklar ise, kadını metalaştırmaktan ve cinsel bir obje haline getirmekten öteye gidememektedir. Şu bakış açısı önemli bir zihniyeti yansıtmaktadır: Fuhuş yapan kadınlar seks işçisi şeklinde kavramsallaştırıldığında, hatta sigortalandığında hakları korunmuş mu olmaktadır? İște esas kadını yoksullaştırııı bakış açısı budur ve feminizmin temel problemi de dünya sisteminin bu bakış açısından uzak olmaması ve hatta kadına bu paradigma içinden yaklaşmasıdır.

Tabii bu arada geçmişten bu yana geleneksel yaşamın da kadını birçok haklar konusunda mağduriyete uğrattığını görmek lazımdır. Tarlalarda hamile haliyle çalıştırılan, yeni doğan bebeğine yeteri kadar ilgi göstermeden ve duygusal yakınlığa izin vermeden tarlaya sürülen, neredeyse geniş ailenin mülkü haline gelen kadınlara yönelik uygulamalar bu mahrumiyetlerden sadece birkaç örnektir. Burada da kadın, bir şahsiyet, kişilik ve insan olarak değil, yoksullaştırıcı bir bakış açısının etkisiyle konumlandırılmakta ve potansiyelleri öldürülmektedir.

\subsection{Beden}

Beden, özellikle post/modern dönemin aktüel tartışmalarında çok boyutlu olarak analiz edilmektedir. Zira beden üzerinden gündeme gelen ve her türlü toplumsallığın tezahürü olarak analize dahil edilen konular bugün farklı disiplinlerce ele alınmaktadır. Feminizmin beden söylemi de yine Hristiyanlık'taki beden anlayışına bir tepkiyi ifade ediyor gibidir. Genel olarak feminist söylem ilkin, Tanrı’nın erkek sigalarla kendisini ifade etmesini problem yapmaktadır. Buna göre, "Tanrı insanın sahip olduğu biyolojik bir cinsiyet türüne sahip değildir. Hristiyanlığın Tanrı’ya dair dili de, erkek dili, erkek zamiridir ki bu stereotip erkek imajını ortaya çıkarmaktadır." (Young, 2004, s. 166). Böylece erkekler aynı zamanda insanlar ile Tanrı arasındaki dolayımı kuran özneler şeklinde görülür ki, kadınlar da tanrılara erkek dolayımıyla ulaşırlar (Berktay, 2000, s. 27) iddiası öne çıkar. Öncelikle Hristiyanlığın bunu doğrulayacak bazı argümanları olduğunu belirtelim. Ancak İslâm, Tanrı-kadın ilişkilerini erkek üzerinden dolayımlamaz. Fakat burada daha önemli bir nokta vardır; feministlerin kadın bedeninin ikincilleştirilmesine yönelik tepkileri bu söylemlerde izlenmektedir. 
Burada Hristiyanlığın kadın bedenine yönelik oluşturduğu anlayışa değinmek gerekir. Söz gelimi; bakirelik kadın için temsili bir anlam kazanırken, kimi yorumlarda Havva’nın da böyle cinsiyetsiz bir prototipi ifade ettiği belirtilmektedir (Newman, 1989, s. 173). Yine hepimizin bildiği üzere bakire Meryem de Hristiyan yaşamının modelidir (Young, 2004, s. 168). Bu da aslında cinselliğin normal sınırlarda yaşanmaması sebebiyle sağlıksız bir bakış açısıdır. Nitekim "Üçüncü Mucize" filminde yer alan bir fahişe, kadın için kutsal kadın ya da fahişe olmaktan başka hayatın önerebileceği bir şey olup olmadığını sormaktadır ki, bu soru Hristiyanlık ve Batı düşüncesini anlamak için önemlidir. Kadın bedenine yönelik argümanlardan birisi de onun bedeninin yani cinselliğinin anormalliği (Higonnet, 2005, s. 297) ve tehlikeli kadın cinselliği söylemidir (Walkowitz, 2005, s. 348). Bu argümanın önemli sonuçları vardır. Her şeyden önce kadın bedeni salt cinsellik boyutuyla algılanmakta ve nihayetinde böyle bir "tehlikeli cinselliğin" kontrol edilmesi zarureti gündeme gelmekte ve nihayetinde bu cinselliğin kontrolü erkeğe verilmek istenmektedir. Bu algılayış biçiminin, kadını cinsel bir metaya indirgeme anlayışıyla örülü olduğu muhakkaktır ve neticede kadının farklı boyutlarını görmezden geldiği için yoksul bir bakış açısıdır. Kur'an, insan ve özelde kadın bedenini cinselliğe indirgemez ve hatta Yûsuf sûresi örneğinde olduğu gibi kadın cinselliğini negatif bir içerikle anlatmaz (Ahmed, 2004, s. 65).

Kadın cinselliğinin kontrolü daha da ilerletilerek toplum ve kamuya aidiyetle bağlantılandırılması da bir problemdir. Böylece kadın bedeni toplumda yeni eksenler içinde bir tanımlamanın konusu olabilmekte ve anonimleşmektedir. Illich bunu "ana rahmi kamu alanı ilan edildi” (Illich, 1996, s. 156) şeklinde ifadelendirmektedir. Türkiye örneğinde de kadınların beden ve cinselliklerini kimi zaman aile, aşiret ya da topluma ait gören hakim bir anlayışın varlığından bahsedilebilir (İlkkaracan, 2004, s. 11). Daha üst düzeyde, iktidarlar da kadın bedenini bu yönde araçsallaştırmışlardır. Söz gelimi; faşist Almanya, İtalya ve İspanya gibi toplumlarda, kadını ailede kocaya ve çok çocuk doğurarak nasyonal-sosyalist devlete hizmet etmesi gereken aşağı bir yaratık olarak gören araçsal bakış açısı sistemleştirilmiş ve bir doktrin haline getirilmiştir. Nazi Almanyası 3 K (çocuk, mutfak, kilise) sloganını benimsemiştir. Kamu işlerinde çalışan evli kadınları bir kararnameyle işten çıkaran ilk ülke de Almanya olmuştur (Michel, 1993, s. 95). İslâm’ın mantalitesinde kadın ise, tıpkı erkek gibi bedeninden sorumlu olup bunun hesabını yalnızca Allah'a verir.

Tabii burada önemli bir noktaya temas etmeliyiz. Gerek Hristiyanlığın gerekse geleneksel bakış açısının kadınlara yaklaşımlarında ciddi problemler vardır ve öncelikli problem, kadını bir kimlik, kişilik ve kendinden sorumlu bir varlık olarak görmeyişleridir. Feminizmin bu bağlamda itirazları bulunduğunu ve bu itirazlarında kısmi haklılığının olduğunu tekrar belirtelim. Peki bunun karşısında feminist söylem ne tür argümanlarla karşımıza çıkmaktadır? Feminist söylem, gerçekte bu algılayışları sağlıklı bir zemine çekmesi gerekirken, o da bir başka uca götürmektedir.

Feministler bu konuda tipik bir biçimde daha retçi bir tutum geliştirmekte ve beden üzerinde yegane egemenin bizzat kadının kendisi olması gerektiğini savunmaktadır- 
lar. Nitekim hepimizin bildiği "bedenim benimdir" sloganı bunu anlatmaya yöneliktir. Zikredilen mottoyu feminizmin bir beden felsefesi kabul edersek, buna göre onların doğum kontrolü, kürtaj hakkı, cinsellikle doğurganlığın birbirinden ayrılması gibi taleplerini (Michel, 1993, s. 117) daha iyi kavrarı. Kadın bedenine yönelik bu taleplerin doğal sonuçları olduğu kadar bir hayat tarzına referansta bulunduğunu da belirtmemiz gerekmektedir. Meselâ; 1920'den beri Fransız feministi Nelly Roussel'ın, cinsellikle doğurganlığın birbirinden ayrılması gerektiği savunusu, hatta doğurmaya karş1 doğurma grevi önerisi (Michel, 1993, s. 86-92) beden üzerinde yegane egemenin kadın olduğunu ilan etmekteydi. Dikkat edilirse burada feminizmin iki önemli problemi vardır. İlki, bu retçi tutumun toplum için bir değer üretme ve katkıda bulunma bakımından negatif tavır doğurmasıdır. Aslında "doğurmama grevi", kadının bizzat kendisini gerçekleştirmesi açısından da yoksullaştırıcı bir tavır olarak görünmektedir. İkincisi de, kendisi de verili dünyanın bir parçası olan kadın ile Tanrı arasındaki ilişkide problem yaratmaktadır. Çünkü İslâm açısından da insan bedeni emanet olup, kişi onun üzerinde egemen değildir. İște tam da bu sebeple zina, kürtaj ve intihar gibi kadının kendi üzerindeki negatif tasarrufları olumsuz karşılanmaktadır.

Feminizm, aslında daha da ileri giderek evliliğin, ailenin, heteroseksüel seks kurumunun ortadan kaldırılmasını ve üreme için rahim dışı yolların geliştirilmesini de savunmaktadır (Donovan, 2001, s. 272). Dolayısıyla serbest cinsel ilişki, homoseksüellik de feminizm açısından meşrulaşmış olmaktadır. Burada erkek ve kadının evlilik yoluyla birbirine aidiyeti, aşk, duygusal süreklilikler, hem kadın hem de erkek için insani bir durum olarak göz önüne alınmamaktadır. Belki bu noktada De Beauvoir’nn şu sözünü hem insan ve kadın gerçeğini bir itiraf, hem de feminizmin yoksullaştırıcı bakış açısına bir eleştiri olarak anlamak mümkündür: "Ancak benim kendimi ona sakladığım gibi, o da kendini bana saklamış olursa, aşkımız tam ve kaçınılmaz olurdu." (De Beauvoir, 2006, s. 191). Anlaşılmaktadır ki aile, evlilik, aidiyet, karnında bir canlıyı hissetme, topluma bir değer üretme gibi pozitif öge ve deneyimler feminizm tarafından kadını zenginleştirici kabul edilmemektedir ve her şeyi bir metaya indirgeyerek (söz gelimi rahim dışı yollarla çocuk edinme) kadınları yoksullaştırmaktadır.

\section{Sonuç}

Bugün ruhun ikinci plana itildiği ve beden üzerine odaklanılan bir dünyada ve kültür içinde yaşamaktayız. Bu durum beden üzerindeki oynamaları ve değiştirmeleri olabildiğince arttırmıştır. Kadın için ideal beden ölçülerinin belirlenmesi, çeşitli diyet sistemleri, estetik ve yağ aldırma operasyonları, kozmetiğin ciddi bir sektör haline gelmesi ile beden daha çok dışarıdan müdahalenin konusu olmaktadır. Hiç şüphesiz bu durum, kadın üzerinde dünya sisteminin bir iktidarı, yeni bir kadın kurgusu; aslında kadını sömürmenin bir başka biçimidir. Nitekim bedene yönelik bu operasyonların medya ile meşrulaşması ve yaygınlaşması sonucu, asgari ücretle çalışmak zorunda 
olan birçok kadının parası tekrar sisteme geri dönmekte; kadın sömürülürken maddi ve manevi yoksullaşmadan bir türlü kurtulamamaktadır. Feminizmin beden üzerinde egemenlik ilan ederken, bu yoksullaş(tır)mayı gör(e)memesi, bir başka yoksulluk örneği olarak da karşımıza çıkmaktadır.

\section{Kaynakça}

Ahmed, L. (2004). “Arap Kültürü ve Kadınların Bedenlerinin Yazılışı”, Müslüman Toplumlarda Kadın ve Cinsellik”, Müslüman Toplumlarda Kadın ve Cinsellik, Der. Pınar İlkkaracan, Çev. Ebru Salman, 2. bs., İletişim Yayınları.

Alexandrıan (1993). Erotik Edebiyat Tarihi, Çev. Işı1k Ergüden, İstanbul: Mitos Yayınları.

Berktay, F. (2000). Tektanrılı Dinler karşısında Kadın-Hristiyanlıkta ve İslamiyette Kadının Statüsüne Karşılaştırmalı Bir Yaklaşım, 2. bs., İstanbul: Metis Yayınları.

Butler, J. (2009). “Toplumsal Cinsiyet Düzenlemeleri”, Cogito, S. 58, İstanbul: Yapı Kredi Yayınları.

Chesser, E. (1972). İlk Gençlik Çağının Cinsel İlişkileri, Çev. Nihal Önol, İstanbul: Varlık Yayinları

Coward, R. (t.y.). Kadınlık Arzuları-Günümüzde Kadın Cinselliği, Çev. Alev Türker, İstanbul: Ayrıntı Yayınları.

Çaha, Ö. (2010). Sivil Kadın-Türkiye’de Kadın ve Sivil Toplum, 2. bs., Ankara: Savaş Yayınları. Çalışlar, O. (1991). İslamida Kadın ve Cinsellik, 3. bs., İstanbul: Afa Yayınları.

De Beauvoir, S. (1977). The Second Sex, Trans. H. M. Parsley, 7th Edition, Great Britain: Penguin Books.

De Beauvoır, S. (2006). Bir Genç Kızın Anıları, Çev. Seçkin Selvi, 7. bs., İstanbul: Payel Yayınlar1.

Donovan, J. (2001). Feminist Teori, Çev. Aksu Bora vd., 2. bs., İstanbul: İletişim Yayınları.

Eflatun (1988). Devlet, Çev. S. Eyüboğlu-M.Ali Cimcoz, 6. bs., İstanbul: Remzi Kitabevi.

Erhat, A. (2003). Mitoloji Sözlüğü, 12. bs., İstanbul: Remzi Kitabevi.

Felski, R. (2000). “The Doxa of Difference”, Provaking Feminisms, Ed. C. Allen-J.A. Howard, Chicago: The University Chicago of Press.

Grannessi, B. (2004). "Voiceless Women-Observe, But From the Centre”, European Journal of Women's Studies, Vol: 11/4, London: Sage Publication.

Gıddens, A. (2010). Mahremiyetin Dönüşümü-Modern Toplumlarda Cinsellik, Aşk ve Erotizm, Çev. İdris Şahin, 2.bs., İstanbul: Ayrıntı Yayınları.

Gölcük, Ş. ve S. Toprak. (1988). Kelam, Konya: S.Ü. Yayınları.

Hıgonnet, A. (2005). “Kadın Temsilleri”, Kadınların Tarihi, c. IV, Ed. Georges Duby-Michelle Perrot, Çev. Ahmet Fethi, İstanbul: T.İş Bankası Yayınları.

Illıch, I. (1996). Gender, Çev. Ahmet Fethi, Ankara: Ayraç Yayınları.

İlkkaracan, P. (2004). “Giriş: Müslüman Toplumlarda Kadın ve Cinsellik”, Müslüman Toplumlarda Kadın ve Cinsellik, Der. Pınar İlkkaracan, Çev. Ebru Salman, 2. Bs., İletişim Yayınları.

İlyasoğlu, A. (1994). Örtülü Kimlik-İslamcı Kadın Kimliğinin Oluşum Ögeleri, 2. bs., İstan- 
bul: Metis Yayınları.

Kurk, A. (1987). "Theology From the Feminist Perspective", Men, Women and God, Ed. Kathy Keay, London: Marshall Pickering.

Kutsal Kitap (2009). İstanbul: Kitab-1 Mukaddes Şirketi.

Kur'an-ı Kerim (1993). Çev. Komisyon, Ankara: T.D.V. Yayınları.

Lloyd, G. (1996). Erkek Akıl-Batı Felsefesinde "Erkek" ve "Kadın", Çev. Muttalip Özcan, İstanbul: Ayrıntı Yayınları.

Mıchel, A. (1993). Feminizm, İstanbul: İletişim Yayınları.

Newman, B. (1989. Sister Of Wisdom-St Hildegard's Theology of the Feminine-With a New Preface, Bibliography and Discography, Los Angele: University of California Press.

Özel, İ. (1993). Bakanlar ve Görenler, 4. bs., İstanbul: Çıdam Yayınları.

Phillıps, A. (1987). "Introduction", Feminism and Equality, Ed. Anne Phillips, New York: New York University Press.

Polonsky, D. C. (1997). Cinsellik Hakkında Konuşamadıklarımız, Çev. Gülden Tümer, Ankara: HYB Yayınları.

Reıch, W. (1980). Cinsel Devrim, Çev. Bertan Onaran, 3. bs., İstanbul: Payel Yayınları.

Sabbah, F. A. (1995). İslamıın Bilinçaltında Kadın, Çev. Ayşegül Sönmezay, 2. bs., İstanbul: Ayrıntı Yayınları.

Saraçgil, A. (2005). Bukalemun Erkek, Çev. Sevim Aktaş, İstanbul: İletişim Yayınları.

Sirman, N. (1995). “Köy Kadınının Aile ve Evlilikte Güçlenme Mücadelesi”, 1980’ler Türkiye’sinde Kadın Bakış Açısından Kadınlar, 3. bs., İstanbul: İletişim Yayınları.

Tekin, M. (2004). Kutsal, Kadın ve Kamu, İstanbul: Açllımkitap Yayınları.

Tong, R. P. (2006). Feminist Düşünce, Çev. Zafer Cirhinlioğlu, İstanbul: Gündoğan Yayınları.

Walkowitz, J. R. (2005). “Tehlikeli Cinsellikler”, Kadınların Tarihi, c. IV, Ed. Georges Duby-Michelle Perrot, Çev. Ahmet Fethi, İstanbul: T. İş Bankası Yayınları.

Wollstonecraft, M. (2007). Kadın Haklarının Gerekçelendirilmesi, Çev. Deniz Hakyemez, İstanbul:T. İş Bankası Kültür Yayınları.

Young, P. D. (2004). “Women in Christianity”, Women and Religious Tradition, Ed. Leona M. Anderson-Pamela D. Y., Canada: Oxford University Press. 